\title{
Histopathological and ultrastructural studies on a novel pathological condition in Solea senegalensis
}

\author{
M. Constenla*, F. Padrós \\ XRAq (Generalitat de Catalunya), Departament de Biologia Animal, de Biologia Vegetal i d'Ecologia, Facultat de \\ Veterinària, Universitat Autònoma de Barcelona, Bellaterra (Cerdanyola del Vallès), Barcelona 08193, Spain
}

\begin{abstract}
A new parasitic disease affecting cultured sole Solea senegalensis (Kaup, 1858) is characterised by the presence of external protuberances in the skin of the affected fish. These lesions correspond to nodules in the muscular tissue showing an abscess-like aspect. Similar lesions were found in the kidney, heart, liver and digestive tract. Histological sections of these nodules revealed the presence of a large core formed mainly of necrotic tissue surrounded with fibroblasts and macrophages. Round-shaped plasmodial organisms were found in the external layer of the nodules and usually inside macrophages or fibroblasts. These organisms were also observed in the intestinal mucosa inside phagocytic cells or parasitophorous vacuoles within the enterocytes. The morphological and ultrastructural characteristics of these organisms are similar to the morphology of some groups of parasites described as fish pathogens. The main features suggest that these organisms could be amoebae or parasites with an amoeboid or plasmodial form in their developmental cycle.
\end{abstract}

KEY WORDS: Solea senegalensis $\cdot$ Flatfish $\cdot$ Histopathology $\cdot$ Granuloma $\cdot$ Parasite Resale or republication not permitted without written consent of the publisher

\section{INTRODUCTION}

Senegalese sole Solea senegalensis culture has aroused a noticeable interest in aquaculture due to its good zootechnical characteristics and commercial value (Cañavate 2005). However, in recent years an increasing number of pathologies seem to hinder its expansion.

The main pathological problems which have been detected are bacterial diseases, mainly pasteurellosis and flexibacteriosis. Pasteurellosis, caused by Photobacterium damsela ssp. piscicida, and flexibacteriosis, caused by Tenacibaculum maritimum, were described some years ago affecting cultured sole in southwest Spain (Zorrilla et al. 1999, Cepeda \& Santos 2002). Recently, other Tenacibaculum species such as T. solea and T. discolor were also isolated from diseased Solea senegalensis (Piñeiro-Vidal et al. 2008a,b). Vibrio harveyi and $V$. alginolyticus are other pathogenic bacteria which were described in S. senegalensis by Zorrilla et al. (2003) and usually appeared in clinical cases as secondary infections associated with T. maritimum (Padrós et al. 2003). Lymphocystis virus and Birnavirus were also isolated from cultured sole (Rodríguez et al.
1997, Alonso et al. 2005). In contrast, there is limited information about parasitic diseases affecting cultured Senegalese sole. Some sporadic infections by protozoan parasites like flagellates or ciliates have been found (F. Padrós pers. obs.), and Palenzuela et al. (2007) described an infection by Enteromyxum scophthalmi in sole cohabiting with infected turbot.

In the last 2 yr a previously undescribed pathology was found in Solea senegalensis in some farms off the European Atlantic coast. This pathological condition was characterised by low mortality and was observed in juveniles, mainly emerging with the rise of temperature in spring. The affected fish usually presented a lethargic behaviour with sporadic, erratic swimming. Some of these fish showed protuberances arising from the skin surface and, in some cases, these lesions were ulcerated.

The aim of the present study was to give a complete characterisation of the main histopathological alterations associated with this problem in the different organs of Senegalese sole, as well as a description of the organisms found in these lesions, in order to provide a tentative identification of the aetiology of this disease. 


\section{MATERIALS AND METHODS}

A total of 20 symptomatic Senegalese sole were sampled at the end of 2007 and during 2008 from 2 fish farms where the disease was detected. Moreover, 2 groups of 15 apparently asymptomatic Senegalese sole were randomly sampled in the same facilities in March and April 2008. Blood was extracted from the caudal vein of 5 symptomatic sole and blood smears were stained with a quick stain (Diff-quick ${ }^{\circledR}$ ).

Fish were immediately killed by spinal severance, measured and weighed. Samples of the affected organs from symptomatic sole and samples of liver, spleen, kidney, digestive tract, gills, muscle and heart from asymptomatic sole were dissected, fixed in $10 \%$ buffered formalin and processed by routine histology. Sections were stained with haematoxylin and eosin (H\&E), and some of these sections were additionally stained with Giemsa and Gram stains.

Small portions of the lesions in muscle were processed for transmission electron microscopy (TEM). Samples were fixed in $2.5 \%$ glutaraldehyde in $0.1 \mathrm{M}$ cacodylate buffer ( $\mathrm{pH} 7.4$ ), postfixed in $1 \%$ osmium tetroxide and embedded in Epon 812 resin. Ultra-thin sections were stained with uranyl acetate and lead citrate prior to examination under a Hitachi H-700 transmission electron microscope.

\section{RESULTS}

Macroscopic lesions consisted of nodules with an abscess-like aspect located in the muscular tissue and also in small nodules in the liver, digestive tract, heart and kidney. These nodules were clearly distinguishable from the rest of the tissues and presented a soft and liquefied consistency. In the digestive tract, these nodules seemed to have a harder consistency.

All of the symptomatic fish, $6 \%$ of the asymptomatic fish sampled in March and $80 \%$ of the asymptomatic fish sampled in April showed histological lesions.

Histological sections of the nodules revealed the presence of chronic inflammatory areas displaying a relatively common pattern in all of the affected tissues, although some differences between tissues and organs could also be found. These inflammatory areas presented a large core of homogeneous necrotic tissue surrounded by fibroblasts and macrophages (Figs. 1, 2 \& 3). The presence of granulocytes in these lesions was usually low. No organised fibrous capsule was detected. The width and extent of the layer formed by macrophages and fibroblasts seemed to be tissuedependent, and was usually more intense in the kidney, moderate in the digestive tract, heart and liver and low in the muscle. However, the effect of the response time of the inflammatory reaction should also be taken into account. In the kidney, the inflammatory reaction consisted of several layers of inflammatory cells and calcified material among necrotic material (Fig. 2). In the digestive tract, heart and liver the inflammatory reaction was usually less intense (Fig. 3). In the liver, in some cases, a significant exudative reaction was found in the external layer of the inflammatory lesion. The inflammatory response in muscle was usually weak, with some infiltration of inflammatory cells among muscle fibres (Fig. 1).

Between the external inflammatory reaction and the necrotic tissue, a zone with abundant macrophages harbouring spherical plasmodial organisms was observed in most cases (Fig. 4). These organisms were observed within the cytoplasm of the macrophages and showed a single nucleus and 1 or 2 basophilic bodies (Fig. 5).

In some cases, extensive necrosis and diffuse inflammatory areas were also found in muscle and liver. In these cases, multiple plasmodial organisms could be observed in the hepatic parenchyma (Fig. 6) and among muscle fibres (Fig. 7). In addition, these organisms were also observed in the mucosal epithelium of the digestive tract inside phagocytic cells or inside apparently parasitophorous vacuoles within the enterocytes (Fig. 8), without a surrounding inflammatory response. Only in the most intense cases was the intestinal mucosa clearly affected, showing an undulating aspect. Organisms in the intestinal epithelium were observed in $43 \%$ of asymptomatic sole and $40 \%$ of symptomatic sole.

Blood samples had a normal appearance and in no cases were plasmodial organisms observed.

The ultrastructural study confirmed macrophages as the most common location of the plasmoidal organisms. Within the cytoplasm of the macrophages, usually a single organism was observed; however, groups of 2, 3 or more organisms could also be observed (Fig. 9). These organisms were 2 to $5 \mu \mathrm{m}$ in diameter and had a vesicular nucleus with marginated chromatin and one central nucleolus (Fig. 10). In some cases, the plasma membrane of these organisms presented slender cytoplasmatic projections (Fig. 11), and round to elongated electron-dense bodies $(0.7$ to $0.3 \mu \mathrm{m}$ ) were found associated with the external layer of this membrane (Fig. 12). The cytoplasm mainly contained lysosomes, different types of digestive vacuoles, myelin figures, free ribosomes and intra-cytoplasmatic membranes resembling rough endoplasmic reticulum (Figs. 10, 12 \& 13). Spherical structures with an external halo with a lower electron density and composed of microfibrils were also sometimes observed (Fig. 10), which could be related to exocytic or endocytic channels. No mitochondria were observed in the cytoplasm of these organisms. 

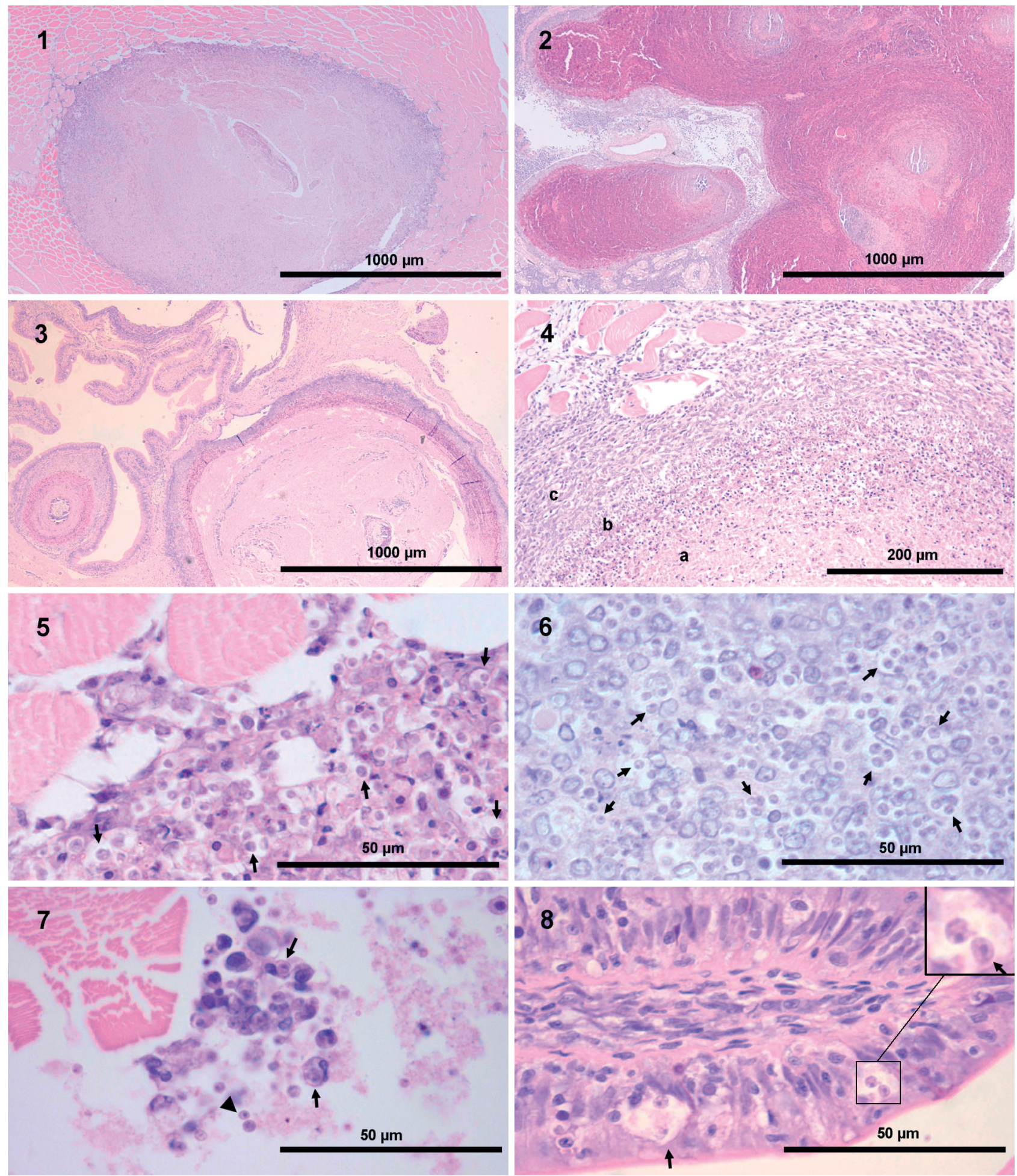

Figs. 1 to 8 . Solea senegalensis. Histological lesions caused by parasites in various organs of Senegalese sole. Stain: H\&E. Figs. 1, 2 \& 3. Inflammatory reaction in muscle, kidney and intestine, respectively. Fig. 4. Lesion in muscle. Several layers are visible: (a) necrotic core, (b) inflammatory area with parasites and (c) external inflammatory reaction. Fig. 5. Round organisms (arrows) inside macrophages in the periphery of a lesion in muscle. Fig. 6. Affected liver with organisms apparently within macrophages in the parenchyma (arrows). Fig. 7. Organisms within macrophages among muscle fibres (arrows). Notice also the presence of extracellular organisms (arrowhead). Fig. 8. Organisms inside phagocytic cells or parasitophorous vacuoles within the intestinal mucosa (arrows), including a detail of the organisms 


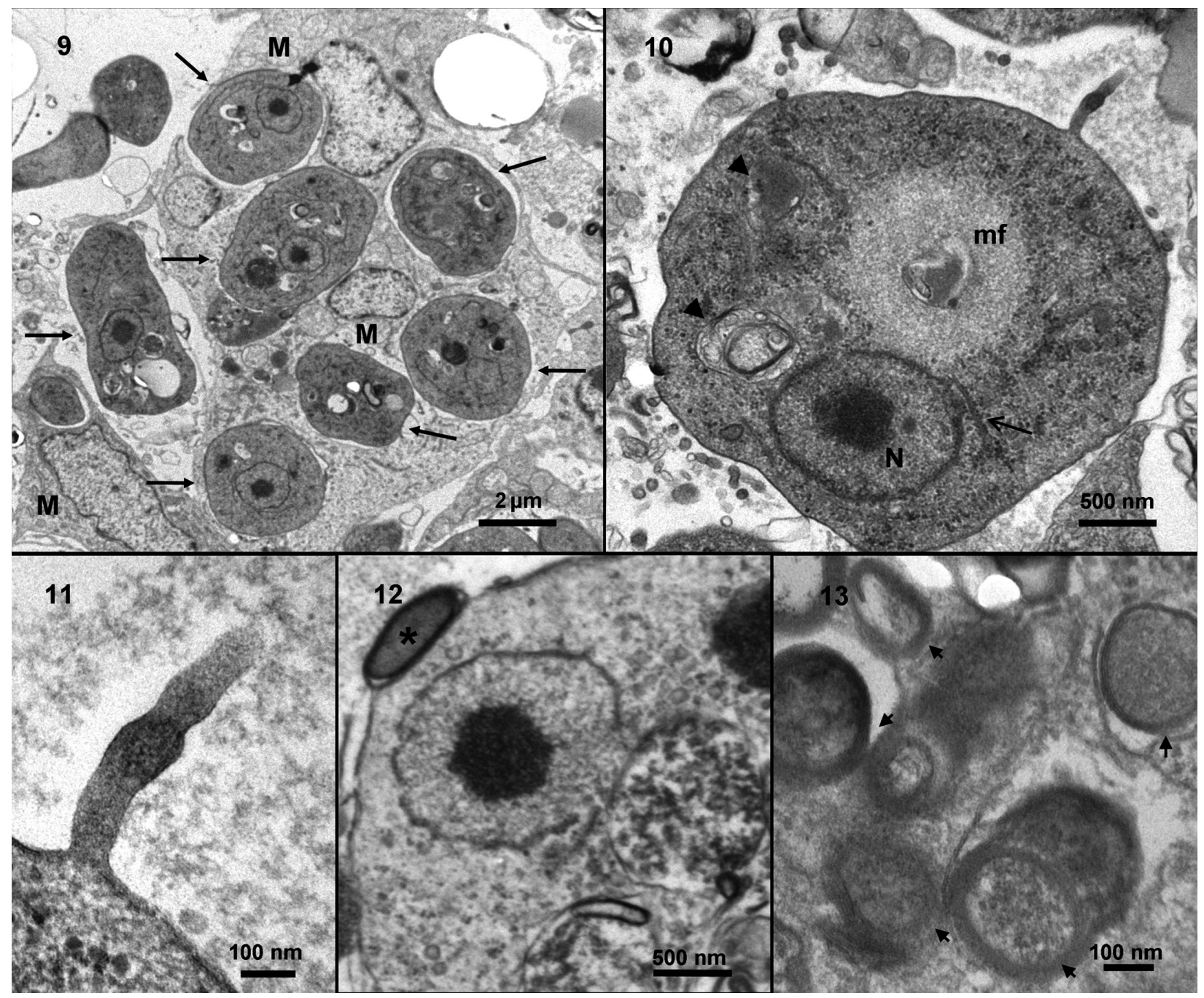

Figs. 9 to 13. Solea senegalensis. Transmission electron micrographs of parasites in muscle of Senegalese sole. Fig. 9. Ultrastructure of the organisms (arrows) within macrophages (M) in a sample of a granulomatous lesion. Fig. 10. Detail of one of these organisms exhibiting a nucleus $(\mathrm{N})$ with a single nucleolus, rough endoplasmic reticulum (arrow), a wide zone of microfilaments (mf) and digestive vacuoles (arrowheads), some with myelin structures. Fig. 11. Detail of a cytoplasmatic projection of the organism in muscle. Fig. 12. Elongated electron-dense body associated with the plasma membrane (asterisk). Fig. 13. Small vacuoles containing several layers of membranous structures in the periphery (arrows)

\section{DISCUSSION}

The present findings indicate that the inflammatory lesions correspond to granulomatous lesions, and the structure of the cells observed within the lesion strongly suggests the parasitic origin of this disease. Furthermore, we did not find any other associated infectious or parasitic pathology. Protozoans of the phylum Sarcomastigophora, such as amoebae or flagellates, the phyla Apicomplexa, Microspora, Mesomycetozoa and the so-called X-cells and metazoans of the class Myxosporean are the main groups to consider. These organisms have a plasmodial or amoebic aspect in their developmental cycles and may cause chronic inflammatory, necrotic or granulomatous responses in different organs.

Granulomatous gastritis was described in systemic infections of the flagellate Cryptobia iubilans in cichlid fish (Yanong et al. 2004), but in our case the apparent absence of flagella and a kinetoplast in a mitochondrion (Dyková \& Lom 2007, Alvarez-Pellitero 2008) does not support the involvement of this group of parasites in the aetiology of this condition.

Similar nodular lesions with accumulations of macrophages and a liquefied core were described in turbot Scophthalmus maximus, related to the hematozoan 
Apicomplexa parasite Haemogregarine sachai (Kirmse 1980) and affecting white blood cells. Similar lesions were also found in Atlantic mackerel Scomber scombrus (MacLean \& Davies 1990) and in gilthead seabream Sparus aurata (Paperna 1979), also related to haemogregarines. However, in the present study we did not find haemogregarines in white blood cells of these fishes nor did we find any ultrastructural characteristic of the Apicomplexa group, such as the typical apical complex, in the parasites.

$\mathrm{X}$-cells, protozoan parasites observed in pseudotumours in fish (Miwa et al. 2004), have also been frequently described in flatfish species (Kent et al. 1988, Miwa et al. 2004) and share some characteristics of amoebic organisms (Watermann 1982). These protistans are large and eosinophilic and have a central and large nucleus with a prominent nucleolus (Miwa et al. 2004). However, they have unusually large mitochondria (Brooks et al. 1969) and are usually surrounded by a matrix of the host cell (Desser \& Khan 1982, Diamant et al. 1994), characteristics not found in the organisms observed in the present study. Moreover, X-cells have not been reported as being intracellular (Freeman 2009) and their size, sometimes $>20 \mu \mathrm{m}$ in diameter (Ito et al. 1976), is much larger than that of the organisms found in the present study.

Dermocystidium sp. (Mesomycetozoa) infections in fish are occasionally characterised by a systemic nodular infection involving visceral organs (Allen et al. 1968, McVicar \& Wootten 1980, Landsberg \& Paperna 1992, Bruno 2001) and share some characteristics with the lesions observed in the present study. However, prominent features of this group include the presence of spores or a thick-walled plasmodium (Bruno 2001, Pekkarinen et al. 2003, Feist et al. 2004, Zhang \& Wang 2005), neither of which were found in the present study.

No characteristic features of Myxozoa, such as 'cellin-cell' stages (Lom \& Dyková 1999, Dyková \& Lom 2007), or of Microsporidia, such as spores, were found in the organisms related to the lesions of Senegalese sole. A myxozoan or microsporidian aetiology is therefore not likely.

According to the morphological and histopathological studies, our observations strongly suggest that amoebae are the group of parasites sharing the most important number of morphological characteristics with the organism found in the present study. Dyková et al. (1996) described a systemic chronic granulomatous inflammatory response associated with amoebalike organisms in goldfish Carassius auratus. These organisms were also detected by light microscopy in the periphery of the granulomas inside a parasitophorous vacuole. Ultrastructurally, the organisms found in the present study and the amoeba-like organisms found in goldfish show a significant number of morphological similarities. The vesicular nucleus with a single, central nucleolus observed in both studies was also observed in other amoebae (Ludvik \& Shipstone 1970, Dyková et al. 1997, Kudryavtsev \& Hausmann 2007), and the cytoplasmatic projections, found in the parasites in the present study, could correspond with amoebic pseudopodia (Dyková \& Lom 2007). Furthermore, vacuoles surrounded by a concentric zone of microfilaments were also observed by Dyková et al. (1996) and in the present study, and in other amoeba species (Dyková et al. 2005). These parasites also have similarities, particularly with the genus Entomaeba, which is characterised by a nucleus with a small central nucleolus and chromatin bodies on the periphery, a reduced Golgi apparatus and a lack of mitochondria.

The prevalence of the parasites in the intestine of symptomatic and asymptomatic sole was quite similar (47 and $43 \%$, respectively). This suggests that these organisms could be endocommensals in the digestive tract and, under specific conditions, these parasites could break the gastrointestinal barrier and invade other parts of the body of the host; however, only the most severe cases would develop into death of the fish. Endocommensals belonging to the genus Entamoeba have been described from the digestive tract of various fish species (Dyková 2008).

Although our preliminary results seem to point towards amoebae as the potential etiological agent, the final identification of these organisms should be made after a more accurate study of the morphological characteristics of the organism, on its hosts and in vitro, and also by a detailed molecular characterisation. At present, molecular studies are in progress in order to verify the precise identification of this organism.

Acknowledgements. We are grateful to Drs. F. E. Montero and O. Palenzuela for their continued support, advice and contributions to this study. We also thank Dr. M. Cuadrado for critically reading the manuscript. M.C.M. benefits from a PIF $\mathrm{PhD}$ student grant of the Universitat Autònoma de Barcelona. We also thank C. Simmons for the English revision of this manuscript.

\section{LITERATURE CITED}

Allen R, Meekin TK, Pauley GB, Fujihara MP (1968) Mortality among Chinook salmon associated with the fungus Dermocystidium. J Fish Res Board Can 25:2467-2475

Alonso MC, Cano I, Garcia-Rosado E, Castro D, Lamas J, Barja JL, Borrego JJ (2005) Isolation of lymphocystis disease virus from sole, Solea senegalensis Kaup, and blackspot sea bream, Pagellus bogaraveo Brünnich. J Fish Dis 28:221-228

Alvarez-Pellitero P (2008) Diseases caused by flagellates. In: Eiras JC, Segner H, Wahli T, Kapoor BG (eds) Fish diseases, Vol 1. Science Publishers, Enfield, NH, p 421-515 
Brooks RE, McArn GE, Welling SR (1969) Ultrastructural observations on an unidentified cell type found in epidermal tumors of flounders. J Natl Cancer Inst 43: 97-109

Bruno DW (2001) Dermocystidium sp. in Scottish Atlantic salmon, Salmo salar: evidence for impact on fish in marine fish farms. Bull Eur Assoc Fish Pathol 21:209-213

Cañavate JP (2005) Opciones del lenguado senegalés Solea senegalensis Kaup, 1858 para diversificar la acuicultura marina. Bol Inst Esp Oceanogr 21:147-154

Cepeda C, Santos Y (2002) First isolation of Flexibacter maritimus from farmed Senegalese sole (Solea senegalensis, Kaup) in Spain. Bull Eur Assoc Fish Pathol 22:388-392

> Desser SS, Khan RA (1982) Light and electron microscope observations on pathological changes in the gills of the marine fish, Lycodes lavalaei Vladykov and Tremblay, associated with the proliferation of an unidentified cell. J Fish Dis 5:351-364

Diamant A, Fournie JW, Courtney LE (1994) X-cell pseudotumors in a hardhead catfish Arius felis (Ariidae) from Lake Pontchartrain, Louisiana, USA. Dis Aquat Org 18:181-185

Dyková I (2008) Amoeboid protists as parasites of fish. In: Eiras JC, Segner H, Wahli T, Kapoor BG (eds) Fish diseases, Vol 1. Science publishers, Enfield, NH, p 397-420

Dyková I, Lom J (2007) Histopathology of protistan and myxozoan infection in fishes. Academia, Prague

Dyková I, Lom J, Machácková B, Sawyer TK (1996) Ameobic infections on goldfishes and granulomatous lesions. Folia Parasitol 43:81-90

Dyková I, Machácková B, Pecková H (1997) Amoeba isolated from organs of farmed tilapias, Oreochromis niloticus. Folia Parasitol 44:81-90

Dyková I, Veverková-Fialová M, Fiala I, Dvoráková H (2005) Protacanthamoeba bohemica sp. n., isolated from de liver of Trench, Tinca tinca (Linnaeus, 1758). Acta Protozool 44:369-376

Feist SW, Longsaw M, Hurrell RH, Mander B (2004) Observations of Dermocystidium sp. infections in bullheads, Cottus gobio L., from liver in southern England. J Fish Dis 27:225-231

Freeman MA (2009) X-cell parasites in the European dab Limanda limanda are related to other X-cell organisms: a discussion on the potential identity of this new group of parasites. Parasitology 136:967-980

Ito Y, Kimura I, Mikaye T (1976) Histopathological and virological investigation of papillomas in soles in coastal waters of Japan. Prog Exp Tumor Res 20:86-93

Kent ML, Myers MS, Wellings SR, Elston RA (1988) An internal X-cell pseudotumor in a black croaker (Cheilotrema saturnum). J Wildl Dis 24:142-145

Kirmse PD (1980) Observation on the pathogenicity of Haemogregarine sachai Kirmse 1978, in farmed turbot Scophthalmus maximus (L.). J Fish Dis 3:101-114

Kudryavtsev A, Hausmann K (2007) Spumochlamys iliensis n.g. n. sp. (Testacealobosia, Microchlamyiidae) from Central Asia, with notes on the diversity of Microchlamys-like testate amoebae. Eur J Protistol 43:185-191

Landsberg JH, Paperna I (1992) Systemic granuloma in goldfish caused by a Dermocystidium-like aetiological agent. Dis Aquat Org 13:75-78

Lom J, Dyková I (1999) Myxosporea (Phylum Myxozoa) In: Woo PTK (ed) Fish diseases and disorders, Vol 1: proto-

Editorial responsibility: Dieter Steinhagen,

Hannover, Germany zoan and metazoan infections, 2nd edn. CABI Publishing, Wallingford

Ludvik J, Shipstone AC (1970) The ultrastructure of Entamoeba histolytica. Bull World Health Organ 43:301-308

MacLean SA, Davies AJ (1990) Prevalence and development of intraleucocytic haemogregarines from northwest and northeast Atlantic mackerel, Scomber scombrus. J Fish Dis 13:59-68

McVicar AH, Wootten R (1980) Disease in farmed juvenile Atlantic salmon caused by Dermocystidium sp. In: Ahne W (ed) Fish diseases. Springer-Verlag, Berlin, p 165-173

- Miwa S, Nakayasu C, Kamaishi T, Yoshiura Y (2004) X-cells in fish pseudotumors are parasitic protozoans. Dis Aquat Org 58:165-170

Padrós F, Zarza C, Estévez A, Crespo S, Furones MD (2003) La patología como factor limitante para el desarrollo del cultivo del lenguado. In: Abstract book, 12-16 May 2003, IX Congreso Nacional de Acuicultura, Cádiz, p 343

Palenzuela O, Redondo MJ, López E, Álvarez-Pellitero P (2007) Cultured sole, Solea senegalensis is susceptible to Enteromyxum scophthalmi, the myxozoan parasite causing turbot emaciative enteritis. Parassitologia 49:73 (Abstract)

Paperna I (1979) Sporozoan infection in cultured Sparus aurata L. and wild Siganus luridus. Ann Parasitol Hum Comp 54:385-392

Pekkarinen M, Lom J, Murphy CA, Ragan MA, Dyková I (2003) Phylogenetic position and ultrastructure of two Dermocystidium species (Ichthyosporea) from the common perch (Percha fluviatilis). Acta Protozool 42:287-307

Piñeiro-Vidal M, Carballas CG, Gómez-Barreiro O, Riaza A, Santos Y (2008a) Tenacibaculum soleae sp. nov., isolated from diseased sole (Solea senegalensis Kaup). Int J Syst Evol Microbiol 58:881-885

Piñeiro-Vidal M, Riaza A, Santos Y (2008b) Tenacibaculum discolor sp. nov. and Tenacibaculum gallaicum sp. nov., isolated from sole (Solea senegalensis) and turbot (Psetta maxima) culture systems. Int J Syst Evol Microbiol 58: $21-25$

Rodríguez S, Vilas MP, Gutierrez MC, Pérez-Prieto I, Sarasquete $\mathrm{MC}$, Rodríguez B (1997) Isolation and preliminary characterization of a Birnavirus from the sole Solea senegalensis in southwest Spain. J Aquat Anim Health 9: 295-300

- Watermann B (1982) An unidentified cell type associated with an inflammatory condition of the subcutaneous connective tissue in dab, Limanda limanda L. J Fish Dis 5:257-261

> Yanong RPE, Curtis E, Russo R, Francis-Floyd R and others (2004) Cryptobia iubilans infection in juvenile discus. J Am Vet Med Assoc 224:1644-1650

Zhang Q, Wang Z (2005) Dermocystidium sp. infection in cultured juvenile southern catfish Silurus meridionalis in China. Dis Aquat Org 65:245-250

- Zorrilla I, Balebona MC, Moriñigo MA, Sarasquete C, Borrego JJ (1999) Isolation and characterization of the causative agent of pasteurellosis, Photobacterium damsela spp. piscicida, from sole, Solea senegalensis. J Fish Dis 22:167-172

Zorrilla I, Arijo S, Chabrillon M, Diaz P, Martinez-Manzanares E, Balebona MC, Moriñigo MA (2003) Vibrio species isolated from diseased farmed sole, Solea senegalensis (Kaup), and evaluation of the potential virulence role of their extracellular products. J Fish Dis 26:103-108

Submitted: November 19, 2009; Accepted: April 27, 2010

Proofs received from author(s): June 17, 2010 